\title{
Are reported stress and coping style associated with frequent recurrence of genital herpes?
}

\author{
Linda Cassidy, Jean Meadows, Jose Catalán, Simon Barton
}

\begin{abstract}
Objectives: This paper reports on the cross sectional data from the longitudinal study examining the impact of genital herpes simplex virus (HSV) infection on quality of life. In particular the report sought to study the relation between recurrence of genital HSV and coping style, mood, personality, and quality of life, among other factors.

Setting and subjects: 116 patients with a known history of genital herpes simplex infection attending the Department of Genitourinary Medicine at Chelsea and Westminster Hospital.

Methods: Psychosocial factors (stress, anxiety, depression, health locus of control, personality, social support, coping skills, and quality of life) and the reported frequency of genital herpes episodes were measured using self administered questionnaires designed to examine the relation between psychosocial status and the frequency of genital HSV episodes.

Results: The number of recurrences reported by patients was significantly related to the style of coping skills used. Higher recurrences were less likely to use problem focused coping skills of planning and active coping, and the emotion focused coping skills of positive reinterpretation and growth. There was a significant difference in the number of patients who believed that psychological stress was related to the number of recurrences they experienced. This belief was related to neuroticism on the Eysenck Personality Questionnaire scale, and not to any of the other measures investigated.

Conclusion: The findings suggest that it is the way individuals cope, and their personality characteristics rather than actual levels of psychological stress, that influence their belief in a link between recurrent genital HSV and stress. HSV may become the focus of existing concerns and be viewed as the physical manifestation of stress.

(Genitourin Med 1997;73:263-266)
\end{abstract}

Keywords: herpes simplex virus; stress

\section{Introduction}

Herpes simplex virus (HSV) remains latent in the sacral ganglia following the acquisition or first episode of genital HSV infection. There is a wide variability in the rate of recurrent episodes both across individuals and within individuals over time. Many factors have been suggested which might activate an HSV recurrence including sunlight, cold, concurrent infection, trauma to the skin, food allergy, heat, fatigue, menstrual cycle changes, and stress. ${ }^{1}$ The view that psychosocial factors, in particular stress, play a role in triggering HSV recurrences has been a central belief of many researchers, physicians, and healthcare workers and has often been cited in the literature. ${ }^{2}$ Physicians and patients with genital herpes often cite psychological stress as the most important factor in the reactivation of recurrent $\mathrm{HSV},{ }^{3}$ with up to $86 \%$ reporting that psychological stress triggered their recurrences. ${ }^{4}$ However, research in this area has failed to support this assumption, though several studies have suggested a relation in the case of those who experience most frequent HSV recurrences. ${ }^{56}$ Stress reduction treatment has been found to produce a reduction in the number of recurrences reported in patients with severe recurrent HSV, but the results of this small study involving only four patients requires replication. ${ }^{?}$

Research using a prospective design has not shown a relation between HSV and psychological stress. Patients asked to keep a daily diary of stress and number of recurrences did not report an elevation in stress before or during a herpes recurrence. ${ }^{8}$ Other studies using a retrospective design have supported these negative findings. ${ }^{-13}$ The aim of the current investigation was to examine the relation between psychological factors, including stress, and recurrence of genital HSV, and to clarify the role stress plays in triggering HSV recurrences.

Frequent recurrences, or the ever present potential for recurrences over which an individual has no obvious control, may result in anxiety, frustration, and feelings of helplessness. ${ }^{14}$ Carney et $a l^{15}$ found that anxiety experienced during a first episode of genital HSV was sustained over a 12 month period in those who experienced further recurrences. The reduction of clinical recurrences by antiviral treatment with aciclovir has been shown to reduce anxiety and illness concern experienced by patients. ${ }^{15}$ It remains unclear whether the anxiety produced by recurrent HSV directly contributes to the frequency of reported recurrences.

Other psychological and social factors believed to play a role in genital HSV recurrences and stress include social support, ${ }^{13} 1718$ coping strategies, ${ }^{17}$ and personality. ${ }^{11} 1920$ This paper reports on the cross sectional data from a longitudinal study examining the impact of genital HSV on patients' quality of life, and the role psychosocial factors may have in triggering recurrences. The study aimed to follow 
Table 1 Standard psychosocial measures used

\begin{tabular}{|c|c|}
\hline Questionnaire & Psychosocial factor being measured \\
\hline $\begin{array}{l}\text { Hospital Anxiety and Depression Scale } \\
\left.\text { (HAD; Zigmond and Snaith }{ }^{21}\right)\end{array}$ & \\
\hline Eysenck Personality Questionnaire & Current psychological status \\
\hline (EPQ; Eysenck and Eysenck ${ }^{22}$ ) & Major dimensions of personality \\
\hline $\begin{array}{l}\text { Social Provisions Scale } \\
\text { (SPC: Cussel|23) }\end{array}$ & \\
\hline Multidimensional Health Beliefs Questionnaire & Perceived social support \\
\hline (MHBQ, Wallston and Wallston 25 ) & Health beliefs \\
\hline $\begin{array}{l}\text { Coping Orientations to Problems Experienced } \\
\text { (COPE; Carver et al }{ }^{16} \text { ) }\end{array}$ & Coping mechanisms \\
\hline $\begin{array}{l}\text { Life Experiences Survey } \\
\left(\text { LES; Sarason } \text { et }^{2 l^{24}}\right)\end{array}$ & $\begin{array}{l}\text { The impact and the number of life } \\
\text { events in the past } 6 \text { months }\end{array}$ \\
\hline $\begin{array}{l}\text { The Medical Outcomes Study Instrument } \\
\text { (MOS-36 short form Health survey (SF-36) }\end{array}$ & Assess current health status \\
\hline
\end{tabular}

Table 2 Characteristics of the whole sample, and the recruitment source subgroups

\begin{tabular}{|c|c|c|c|c|c|c|}
\hline & \multicolumn{2}{|c|}{$\begin{array}{l}\text { Whole sample } \\
(n=116)\end{array}$} & \multicolumn{2}{|c|}{$\begin{array}{l}\text { Clinic } \\
(n=91)\end{array}$} & \multicolumn{2}{|c|}{$\begin{array}{l}\text { Media } \\
(n=25)\end{array}$} \\
\hline & $n$ & $\%$ & $n$ & $\%$ & $n$ & $\%$ \\
\hline \multicolumn{7}{|l|}{ Sex: } \\
\hline $\begin{array}{l}\text { Male } \\
\text { Female }\end{array}$ & $\begin{array}{l}48 \\
68\end{array}$ & $\begin{array}{l}41 \cdot 4 \\
58 \cdot 6\end{array}$ & $\begin{array}{l}37 \\
54\end{array}$ & $\begin{array}{l}40 \cdot 7 \\
59 \cdot 3\end{array}$ & $\begin{array}{l}11 \\
14\end{array}$ & $\begin{array}{l}44 \\
56\end{array}$ \\
\hline \multicolumn{7}{|l|}{$\begin{array}{l}\text { Length of time since diagnosis: } \\
\text { Under } 1 \text { year }\end{array}$} \\
\hline $\begin{array}{l}1-5 \text { years } \\
6-10 \text { years } \\
11 \text { years and over }\end{array}$ & $\begin{array}{l}26 \\
44 \\
22 \\
24\end{array}$ & $\begin{array}{l}22.4 \\
37.9 \\
19 \cdot 0 \\
20.7\end{array}$ & $\begin{array}{l}26 \\
33 \\
14 \\
18\end{array}$ & $\begin{array}{l}28 \cdot 6 \\
36 \cdot 3 \\
15 \cdot 4 \\
19 \cdot 8\end{array}$ & $\begin{array}{r}0 \\
11 \\
8 \\
6\end{array}$ & $\begin{array}{r}0 \\
44 \\
32 \\
24\end{array}$ \\
\hline $\begin{array}{l}\text { Mean number of recurrences } \\
\text { in } 6 \text { months (range) } \\
\text { Mean age (years) (range) }\end{array}$ & $\begin{array}{r}3 \cdot 65 \\
35 \cdot 31\end{array}$ & $\begin{array}{r}0-24 \\
21-69\end{array}$ & $\begin{array}{r}3 \cdot 46 \\
34 \cdot 23\end{array}$ & $\begin{array}{r}0-18 \\
22-69\end{array}$ & $\begin{array}{r}4 \cdot 20 \\
39 \cdot 24\end{array}$ & $\begin{array}{r}0-24 \\
21-66\end{array}$ \\
\hline \multicolumn{7}{|l|}{ Type of treatment: } \\
\hline $\begin{array}{l}\text { No specific treatment } \\
\text { Episodic aciclovir }\end{array}$ & $\begin{array}{l}49 \\
41\end{array}$ & $\begin{array}{l}42 \cdot 2 \\
35 \cdot 3\end{array}$ & $\begin{array}{l}30 \\
35\end{array}$ & $\begin{array}{l}33 \\
38 \cdot 5\end{array}$ & $\begin{array}{r}19 \\
6\end{array}$ & $\begin{array}{r}76 \\
24\end{array}$ \\
\hline
\end{tabular}

patients over a one year period as they received appropriate treatment in the clinic.

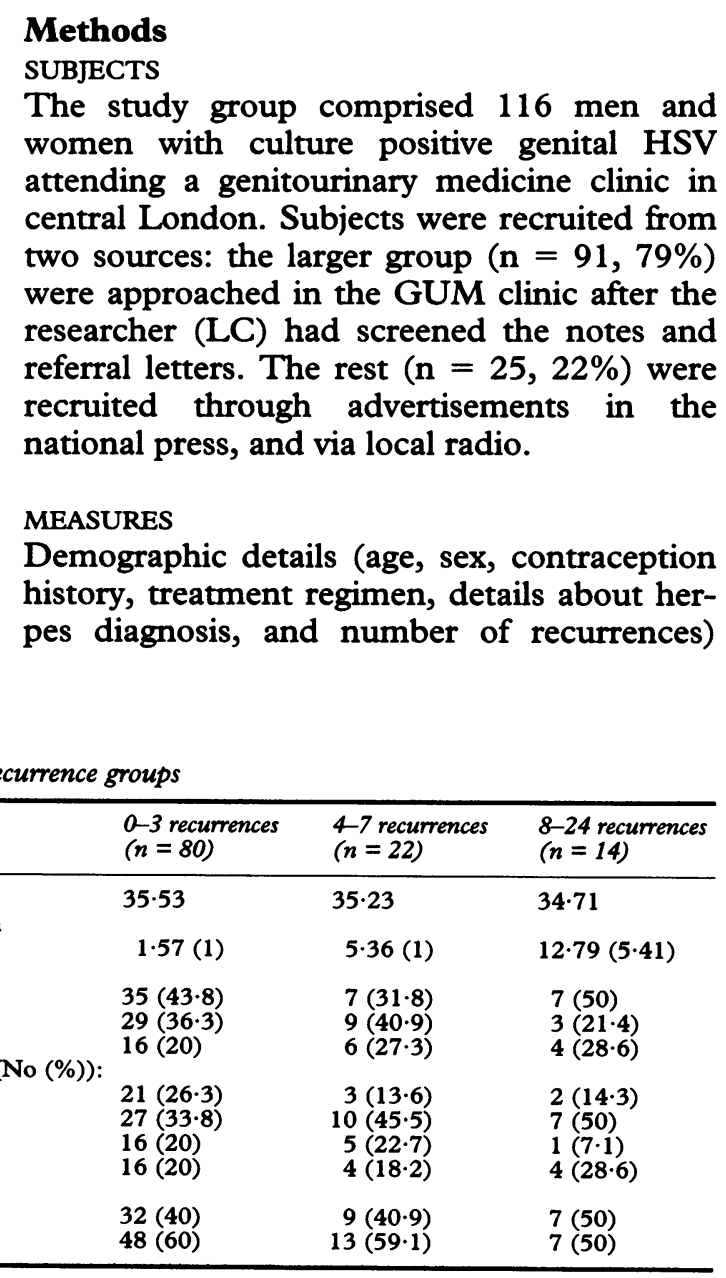

were recorded by the researcher. A battery of standardised psychological and social measures were given to the patients to complete as a questionnaire pack. Details of the measures are given in table 1. They included a measure of anxiety and depression designed to be used with general hospital populations, ${ }^{21}$ a well known personality questionnaire, ${ }^{22}$ and instruments to assess coping style, ${ }^{16}$ perceived social supports, ${ }^{23}$ recent life events, ${ }^{24}$ health beliefs (Wallston and Wallston, Multidimensional Health Beliefs Questionnaire, 1978), ${ }^{25}$ and health related quality of life (MOS-36).$^{26}$

\section{ANALYSIS}

Data were analysed using the Statistical Package for the Social Sciences for Personal Computers (SPSS PC). ${ }^{27}$ Pearson's correlation coefficient was used. One way analysis of variance (ANOVA) was used for group comparisons. $\chi^{2}$ tests were used for non-parametric group comparisons or Fisher's exact test where cell sizes were less than five.

\section{Results}

A total of $116 \mathrm{HSV}$ patients (48 male and 68 female) were recruited to the study, giving a response rate of $89 \%$ of all eligible subjects. At the first assessment $49(42 \cdot 2 \%)$ were receiving no specific treatment, $41(35.3 \%)$ were receiving aciclovir episodically, and $26(22.4 \%)$ were receiving aciclovir suppressively. There were no significant differences between the three treatment groups for any of the psychosocial measures used. As $25(22 \%)$ of the sample were recruited through advertisements, the two recruitment groups were compared on all measures used (table 2). No significant differences were found between the two groups of patients, and so they were treated as one subject group for the purposes of analysis. It must be noted, however, that none of the subjects recruited via the media were diagnosed recently, compared with more than a quarter of clinic subjects.

There were no statistically significant correlations between the number of recurrences reported and the psychosocial measures. As the data for the number of recurrences in the previous six months were skewed, subjects were divided in three groups: those reporting up to three recurrences, those reporting four to seven recurrences, and those reporting eight recurrences or more. This allowed parametric tests to be carried out on the data. (See table 3 for characteristics of recurrence groups.)

\section{PSYCHOLOGICAL AND SOCIAL FACTORS}

Only results on the coping style measure (COPE) showed statistically significant differences by recurrence group. One way ANOVA showed significant differences for three coping styles: (a) active coping, (b) planning, and (c) positive reinterpretation and growth. Tukey's HSD test with a significance level of $p<0.05$ showed that for active coping, the difference was between the moderate and high recurrence groups, the latter reporting the lowest levels of active coping. The high recurrence 
Table 4 Mean scores (SD) for COPE items by recurrence groups

\begin{tabular}{lccc}
\hline & $0-3$ Recurrences & $4-7$ Recurrences & $8+$ Recurrences \\
\hline Active & $13.61(2.73)$ & $14.71(1.95)$ & $12.36(2.47)^{\star}$ \\
Planning & $12.01(2.71)$ & $12.86(2.01)$ & $11.36(2.71)^{\star \star}$ \\
Suppression of competing activities & $11.61(2.83)$ & $12.55(2.44)$ & $10.93(1.59)$ \\
Restraint coping & $13.23(3.76)$ & $14.50(3.00)$ & $13.14(3.37)$ \\
Seeking social support for instrumental & & & \\
$\quad$ reasons & $11.88(2.91)$ & $12.14(2.83)$ & $11.07(3.05)$ \\
Seeking social support for emotional & & & \\
$\quad$ reasons & $11.98(3.24)$ & $12.41(3.11)$ & $10.14(3.59)$ \\
Positive reinterpretation and growth & $11.71(2.73)$ & $12.05(2.70)$ & $9.79(1.85)^{\star}$ \\
Acceptance & $11.60(2.61)$ & $11.73(1.98)$ & $10.21(1.81)$ \\
Turning to religion & $5.69(2.65)$ & $6.05(2.85)$ & $5.43(2.53)$ \\
Focus on and venting of emotions & $11.11(3.56)$ & $11.68(3.03)$ & $10.21(3.45)$ \\
Denial & $5.38(1.89)$ & $5.41(1.84)$ & $5.93(2.84)$ \\
Behavioural disengagement & $6.06(2.09)$ & $6.50(1.90)$ & $6.14(2.03)$ \\
Mental disengagement & $8.29(2.14)$ & $8.59(2.65)$ & $8.43(2.28)$ \\
Alcohol-drug disengagement & $1.59(0.94)$ & $1.91(0.97)$ & $1.79(1.05)$ \\
\hline
\end{tabular}

${ }^{\star} \mathrm{p}<0.05,{ }^{\star \star} \mathrm{p}<0.001$, Tukey's HSD $\mathrm{p}<0.05$

Table 5 Perception of psychological stress as a trigger for herpes recurrences

\begin{tabular}{|c|c|c|}
\hline & $\begin{array}{l}\text { Psychological stress } \\
(n=68)\end{array}$ & $\begin{array}{l}\text { No psychological stress } \\
(n=47)\end{array}$ \\
\hline \multirow{3}{*}{$\begin{array}{l}\text { Mean number of recurrences in } \\
6 \text { months (SD) } \\
\text { Mean number of negative life events } \\
\text { in } 6 \text { months (SD) } \\
\text { Mean HAD anxiety scores } \\
\text { Neuroticism } \\
\text { Number (\%) scoring above the norm } \\
\text { on the neuroticism scale of the EPQ }\end{array}$} & $3 \cdot 85(4 \cdot 20)$ & $3 \cdot 51(4 \cdot 29)$ \\
\hline & $\begin{array}{c}4 \cdot 28(4 \cdot 34) \\
8 \cdot 39(4 \cdot 04) \\
14 \cdot 54 \dagger(4 \cdot 40)\end{array}$ & $\begin{array}{r}5 \cdot 21(5 \cdot 65) \\
7.72(3 \cdot 81) \\
12 \cdot 23(5 \cdot 89)\end{array}$ \\
\hline & $47 \dagger(69)$ & $26(57)$ \\
\hline
\end{tabular}

$\star_{t}=2.03, \mathrm{df}=112, \mathrm{p}<0.05$.

$+\chi^{2}=3 \cdot 142$, df1, $\mathrm{p}<0.05$. of life than those with fewer episodes. Anxiety, depression, health locus of control, personality, and social support were not related to the reporting of genital HSV recurrent episodes. These data accord with the growing number of studies that have not found a relation between the frequency of recurrent genital HSV episodes and stress. ${ }^{8-13}$

We found that those who report a high frequency of recurrences of genital HSV are less likely to use the problem focused coping strategies of planning and active coping. Planning is thinking about how to cope with a stressor and involves devising action strategies, thinking about what steps to take, and how best to handle a problem. Active coping involves taking active steps to try to remove or relieve a stressor or alleviate its effects. It involves initiating direct action, increasing one's efforts and trying to execute a coping attempt in a stepwise fashion. ${ }^{16}$ This study shows that those who report a higher number of recurrences are also less likely to use the coping skill of positive reinterpretation and growth. This is a form of emotion focused coping, aimed at managing distressing emotions rather than the stressor itself. ${ }^{16}$ Our finding is consistent with the view of Folkman and Lazarus that emotion focused coping is important in adjusting to health problems and involves decreasing feelings of fear and threats to self esteem. ${ }^{28}$ If active steps to cope with stress are not taken, individuals may become overconcerned with what they believe to be a physical manifestation of that stress, the frequency of recurrences of HSV, rather than the actual cause of their stress. If they are not able to cope with the emotional distress that results from it, the believed link between stress and genital HSV may strengthen.

The majority of patients in the study believe in a direct causal relation between stress and genital herpes recurrences, supporting previous reports. ${ }^{4}$ This group also scored significantly higher on the neuroticism scale of the Eysenck Personality Questionnaire. This is a stable personality trait that does not change over time. Those scoring highly on the EPQ neuroticism scale are likely to be more anxious, prone to worrying, moody, and depressed. They are likely to have sleep disturbance and to suffer from various psychosomatic disorders. Genital herpes could be seen by such individuals as the physical manifestation of stress, a belief reinforced by healthcare workers and some published reports. As stress is a commonly reported symptom, it is likely that a recurrence will at some time coincide with a period of stress, reinforcing the belief in a causal relation.

In conclusion, in attempting to help individuals experiencing recurrences of genital HSV, efforts to alter their coping style in the direction of greater use of problem and emotion focused strategies are more likely to be of value. In addition, the role of personality factors in relation to health beliefs needs to be further investigated.

This study was supported by a grant from the Wellcome Foundation through the St Stephen's AIDS Trust.

the frequency of reported recurrent episodes of genital HSV and psychological stress as measured by the anxiety and depression scales and by the number of recent negative experiences. Subjects with a high number of reported episodes did not have a lower quality 
1 Corey L, Adams HG, Brown ZA, Holmes KK. Genital herpes virus infections: clinical manifestations, course and complications. Ann Intern Med 1983;98:958-72.

2 Harknett P. Herpes simplex: the self help guide to managing the herpes virus. London: Thorsons, 1994.

3 Hamilton R. The herpes book. Boston: Houghton Mifflin, 1980.

4 Bierman SM. Recurrent genital herpes simplex infection: a trivial disorder? Arch Dermatol 1985;121:513-7.

5 Carney O, Ross E, Bunker C, Ikkos G, Mindel A. A prospective study of the psychological impact on patients of a first episode of genital herpes. Genitourin Med 1994; 70:40-5.

6 Watson D. The relationship of genital herpes and life stress as moderated by locus of control and social support. (Unpublished manuscript) The University of Southern California, Long Beach, 1983.

7 Vanderplate C, Kerrick G. Stress reduction treatment of severe recurrent genital herpes virus. Biofeedback Self Regulat 1985;10:181-8.

8 Rand K, Hoon E, Massey J, Johnson J. Daily stress and recurrence of genital herpes simplex. Arch Intern Med 1990;150:1889-93.

9 Hoon EF, Hoon PW, Rand KH, Johnson J. Psycho-behaviourial model of genital herpes recurrence. F Psychosom Res 1991;35:25-36.

10 Longo DJ, Clum GA. Psychosocial factors affecting genital herpes recurrences. F Psychosom Res 1989;33:161-6.

11 Stout CW, Bloom LJ. Genital herpes and personality. $f$ Hum Stress 1986;12:119-24.

12 Silver SP, Averbach SM, Vishniavsky N, Kaplowitz LG. Psychological factors in recurrent genital herpes infection: stress, coping style, social support, emotional dysfunction stress, coping style, social support, emotional dysfunction

13 Van der Plate C, Aral SO, Magder L. The relationship among genital herpes simplex virus, stress and social support. Health Psychol 1988;7:159-68.

14 Himmell K. Genital herpes: the need for counselling. $f$ Gynaecol Nurs 1981;10:446-50.

15 Carney R, Ross E, Ikkos G, Mindel A. The effect of sup- pressive oral acyclovir on the psychological morbidity associated with recurrent genital herpes. Genitourin Med 1993;69:457-9.

16 Carver C, Scheier MF, Weintraub JK. Assessing coping strategies: a theoretically based approach. $\mathcal{F}$ Pers Soc Psychol 1989;56:267-83.

17 Manne S, Sandler I. Coping and adjusting to genital herpes. F Behav Med 1984;7:391-410.

18 McLarnon LD, Kaloupek DG. Psychological investigation of genital herpes recurrence: prospective assessment and cognitive behaviourial intervention for a chronic physical disorder. Health Psychol 1988;7:231-49.

19 Lacroix JM, Offutt C. Type A and genital herpes. $f$ Psychosom Res 1988;32:207-12.

20 Goldmeier D, Johnson A, Byrne M, Barton S. Psychosocial implications of recurrent genital herpes simplex virus infection. Genitourin Med 1988;64:327-30.

21 Zigmond AS, Snaith RP. Hospital anxiety and depression scale. Acta Psychiatr Scand 1983;67:361-70.

22 Eysenck HJ, Eysenck SBJ. Manual of the Eysenck personality questionnaire. Sevenoaks: Hodder and Stoughton, 1975.

23 Cutrona CE, Russell D. The provisions of social relation ships and adaptation to stress. In: Jones WH, Perlman D, ships and adaptation to stress. In: Jones WH, Perlman D, eds. Advances in

24 Sarason IG, Johnson JH, Siegel JM. Assessing the impact of life changes: development of the life experiences survey. $\mathcal{F}$ Clin Psychol 1978;47:932-46.

25 Wallston KA, Wallston BS, DeVellis R. Development of the multidimensional health lows of control scales. Health Education Monographs 1978;6:161-70.

26 McHorney CA, Ware JE, Raczek AE. The MOS-36 item short form health survey: II. Psychometric and clinical test of validity in measuring physical and mental health test of validity in measuring physical ar

27 Norusis MJ. The SPSS guide to data analysis. 2nd ed. Chicago: SPSS Inc, 1991.

28 Folkman S, Lazarus RS. An analysis of coping in a middle aged community sample. $\mathcal{f}$ Health Soc Behav 1980;21: 219-39. 